\title{
Lung Function Impairment in Construction Workers - Influence of Smoking and Exposure Duration
}

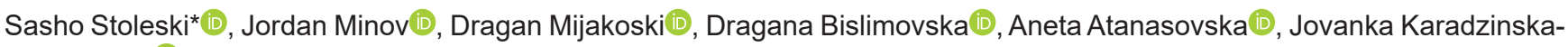 \\ Bislimovska (i) \\ Institute for Occupational Health - Skopje, WHO Collaborating Center, Ga²len Collaborating Center, Skopje, Republic of \\ Macedonia
}

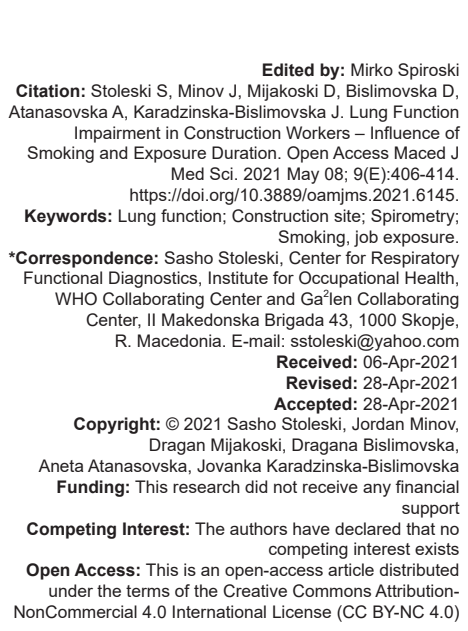

\section{Abstract}

AIM: The objective of the study was to assess the influence of exposure duration and smoking on ventilatory impairment among construction workers.

METHODS: A cross-sectional study was performed, including 83 construction workers aged 18-64 years, compared to equivalent number of office controls matched by age, workplace exposure duration, and smoking status. Data on chronic respiratory symptoms, work history, and smoking status were collected by standardized questionnaire, while lung functional testing of the examined subjects was performed by spirometry.

RESULTS: Mean values of spirometric parameters were lower in construction workers compared to controls with statistical significance registered for maximal expiratory flow $\left(\mathrm{MEF}_{25}\right), \mathrm{MEF}_{50}$, and $\mathrm{MEF}_{75}$. Lung functions of construction workers have been found to decrease in relation to exposure duration but reached significance only for small airways changes. There was a significant difference in detected ventilatory impairment between exposed workers and controls for any type of ventilatory impairment, as well as obstructive and combined ventilatory pattern and obstructive ventilatory pattern in small airways. Obstructive ventilatory impairment was significantly associated with life-time smoking in construction workers, while obstructive ventilatory pattern in small airways was significantly associated with life-time smoking. The combined effect of daily smoking, life-time smoking, and number of cigarettes smoked daily was shown to have a significant influence in their development. The risk for obstructive ventilatory pattern in small airways among exposed subjects was about 4 fold higher in those exposed more than 20 years (odds ratio [OR] $=3.68$ [1.01-14.59] confidence interval [Cl] 95\%), and about 2.5 fold higher in smokers (OR $=2.57$ [0.92-7.25] $\mathrm{Cl} 95 \%$ ). Exposure duration, smoking and age had independent effect only on small airways changes and force expiratory volume in the $1^{\text {st }} \mathrm{s} /$ force vital capacity $\%$.

CONCLUSION: Our data suggest the importance of the joint effect of job exposure in construction and daily smoking on the development of lung function impairment and airflow limitation, being dominant, especially on small airways.

\section{Introduction}

Workplace is an important factor affecting worker's respiratory health [1]. A dusty working environment can increase the risk of inhaling particles that may adversely affect a respiratory system [2]. Activities in the construction sector generate a high concentration of dust, leading to significant respiratory impairment among construction workers [3].

These activities continuously generate hazards, which are often a risk factor for workers' respiratory disorders [4], [5]. Workers exposed to dusts most commonly suffer from lung function impairment. Moreover, construction workers are especially exposed to high concentrations of dust in closed spaces and inhale high levels of crystalline silica [6].

The most common respiratory finding among workers exposed to harmful dust particles is lung function decline [7]. Construction sites generate many forms of dust particles, out of which the main sources include concrete, silica, asbestos, cement, wood, stone, and sand [8]. The use of power handheld tools, together with increased specialization of the construction work in the last decades, lead to increase workers' exposure to dusts over the working hours [7], [9]. Bakke et al. studied the cumulative exposure to respirable dusts in several construction task groups [10].

Construction workers may also experience respiratory problems which are later on associated with changes in chest radiographs and pulmonary function [11]. Evaluation of spirometric parameters allows us to distinguish between obstructive and restrictive pattern of respiratory impairment [12].

Construction sites are sources of dusty environment and risk of inhaling particulate matter for construction workers leading to adverse effects on respiratory system. Cement dust exposure at a construction site can cause a variety of respiratory diseases associated with impaired lung function [13]. The diameter of cement dust particles of $<10 \mu \mathrm{m}$ is within respirable limit, and therefore these particles pose a health hazard to such workers as they easily 
reach the lower respiratory tract leading to lung damage among exposed workers. Lung function tests are essential to detect any such respiratory deterioration [14]. Spirometry testing is crucial when it comes to diagnosing chronic lung disorders. It is well known and documented that certain factors such as occupation and working environment affect respiratory health in exposed workers, besides their other anthropometric variables [15]. Prolonged and continuous exposure to dust particles at construction sites usually increases the risk and accelerates lung function impairment. Recent studies explored the relationship between job exposure and respiratory effects in exposed construction workers and showed the association between cement dust and lung function decline [16].

However, only a limited number of studies are focusing on the status of lung function among exposed construction workers. The present study was conducted to evaluate the degree of lung function impairment among workers at construction sites, comparing them with office workers who are working in a cleaner environment.

This survey was undertaken to explore the pulmonary function among construction workers to make the research on their respiratory health status more profound, having in mind smoking habit and exposure duration. Furthermore, construction industry is growing rapidly in almost every developing country, and therefore, the obtained results can be of great importance for employers in taking preventive measures that maintain and promote worker's health and safety.

\section{Subjects and Methods}

\section{Study design and setting}

A cross-sectional survey was realized by the research team from the Institute for Occupational Health, Skopje - World Health Organization (WHO) Collaborating Center and GA2LEN Collaborating Center within the Center for Respiratory Functional Diagnostics during November 2018-May 2019.

\section{Study sample}

In order to ensure validity of the results, the study sample was calculated by the software program PEPI 4.04, with 95\% confidence level and confidence interval $(\mathrm{Cl}) \pm 5$.

Therefore, having in mind possible selection and response bias, to obtain the requested sample size, we have taken a representative sample of 83 construction workers and compared them with 80 matched office controls.

\section{Subjects}

The team has examined 83 subjects (mean age=53.1 \pm 8.3) employed as construction workers (mean duration of exposure $23.9 \pm 8.2$ ). They work at construction sites which generate a high level of dust, typically from concrete, silica, asbestos, cement, wood, stone, sand, etc. Construction dust is classified as PM-10, that is, particulate matter of $<10 \mu \mathrm{m}$, putting workers at risk of inhaling these particles. Airborne silica dust, to which construction workers are exposed, is mainly generated during chasing or drilling into concrete, bricklaying work, ripping up old concrete, and excavating sites with sandstone or clay. Moreover, they are exposed to various respiratory agents, including fumes, gases, vapors, inappropriate climate, and temperature amplitudes. Inclusion criteria for examined group (EG): subjects within age range 18-64 years employed at construction sites and exposed to occupational respiratory hazard (dusts, gases, fumes, and vapors).

Exclusion criteria for EG: Subjects younger than 18 or older than 64 years and subjects not engaged in construction sites. Depending on the exposure duration, the examined subjects were divided in two subgroups: Exposed less or more than 20 years.

Furthermore, we have studied a similar group of 80 office workers (mean age $=52.9 \pm 8.5$ ) matched for age, duration of employment, daily smoking, and socioeconomic status, as a control group (CG), with no available data on occupational exposure to respiratory hazards.

Subjects who were previously diagnosed by physician to have some chronic respiratory disorder (asthma, COPD, bronchiectasis, sarcoidosis, etc.), or treated with bronchodilators and/or corticosteroids in both groups, were excluded from the study. Furthermore, the study did not include subjects in whom spirometry testing was contraindicated.

The study protocol has been approved by Institute's ethics committee, while every examined subject was informed and gave written consent before any involvement in the survey.

\section{Questionnaire}

All study subjects were interviewed by physician and completed the standardized questionnaire, obtaining answers about work history, respiratory symptoms in the last 12 months, and smoking habit.

Chronic respiratory symptoms in the last 12 months (cough, phlegm, dyspnea, wheezing, and chest tightness) were collected by European Community for Coal and Steel questionnaire (ECCS-87), and European Community Respiratory Health Survey (ECRHS) questionnaire [17], [18].

Smoking status was classified according to the WHO guidelines [19]. Daily smoker was defined as a 
subject who smoked at the time of the field survey at least once a day, except on days of religious fasting. We have also assessed life-time cigarette smoking and daily mean of cigarettes smoked among daily smokers, while pack-years smoked was calculated according to the actual recommendations [20].

Ex-smoker was defined as a formerly daily smoker who no longer smokes.

Passive smoking or exposure to environmental tobacco smoke was defined as the exposure to tobacco combustion products from smoking by others [21].

\section{Baseline spirometry testing}

Spirometry testing was performed in all study subjects, using Ganshorn SanoScope LF8 spirometer (Ganshorn Medizin Electronic $\mathrm{GmbH}$, Germany), with measures of forced vital capacity (FVC), forced expiratory volume in $1 \mathrm{~s}\left(\mathrm{FEV}_{1}\right), \mathrm{FEV}_{1} /$ FVC ratio $\left(\mathrm{FEV}_{1} / \mathrm{FVC} \%\right)$, and maximal expiratory flow at $50 \%, 75 \%$, and $25-75 \%$ of FVC $\left(\mathrm{MEF}_{50}, \mathrm{MEF}_{75}\right.$, and $\mathrm{MEF}_{25-75}$, respectively), by recording the best result from three measurements of the $\mathrm{FEV}_{1}$ values which are within $5 \%$ of each other. The results were expressed as percentages of the predicted values according to the ECCS norms. The spirometry results were given as percent of their predicted values due to the current European Respiratory Society (ERS) and American Thoracic Society (ATS) recommendations, including reproducibility and acceptability [22].

\section{Statistical analysis}

The obtained data were analyzed using Statistica for Windows version 7. Continuous variables were expressed as mean values with standard deviation and categorical variables as numbers and percentages. The Chi-square test (or Fisher's exact test) was used for testing differences in the prevalence of respiratory symptoms, while the comparison of spirometric measurements was performed by independent-samples t-test and MannWhitney $U$ test. A $p<0.05$ was considered statistically significant. Multiple linear regression analyses were used to assess the risk for the development of lung function impairment in construction workers and adjusted for age, exposure duration, and smoking habit. Study variables were checked for normality by Kolmogorov-Smirnov and Shapiro-Wilk's W test.

\section{Results}

Demographic characteristics of the study subjects were similar in both construction workers and office controls (Table 1).
Table 1: Demographics of the study subjects

\begin{tabular}{lll}
\hline Variable & Construction workers $(\mathrm{n}=83)$ & Office workers $(\mathrm{n}=80)$ \\
\hline Age range (years) & $18-64$ & $19-65$ \\
Age (years) & $53.1 \pm 8.3$ & $52.9 \pm 8.5$ \\
BMI $\left(\mathrm{kg} / \mathrm{m}^{2}\right)$ & $25.3 \pm 3.4$ & $25.8 \pm 3.9$ \\
Duration of employment (years) & $26.3 \pm 10.6$ & $25.2 \pm 10.2$ \\
Duration of exposure & $23.9 \pm 8.2$ & $/$ \\
Daily smokers & $39(46.9 \%)$ & $39(48.7 \%)$ \\
Life-time smoking (years) & $19.2 \pm 8.1$ & $18.9 \pm 7.9$ \\
Cigarettes/day & $15.1 \pm 6.7$ & $14.9 \pm 7.1$ \\
Pack-years smoked & $13.1 \pm 4.7$ & $12.8 \pm 4.9$ \\
Ex-smokers & $8(9.6 \%)$ & $11(13.7 \%)$ \\
Passive smokers & $6(7.2 \%)$ & $7(8.7 \%)$ \\
\hline Numerical data are expressed as mean value with standard deviation; frequencies as number and
\end{tabular}
percentage of study subjects with certain variable. BMI: Body mass index; $\mathrm{kg}$ : Kilogram; m: Meter.

Mean values of spirometric parameters are lower in construction workers compared to controls, but statistical significance is registered for $\mathrm{MEF}_{25}, \mathrm{MEF}_{50}$, and $\mathrm{MEF}_{75}$ (Table 2).

Table 2: Mean values of spirometric parameters in construction workers and controls

\begin{tabular}{|c|c|c|c|}
\hline Spirometric parameter & $E G(n=83)$ & CG $(n=80)$ & P-value* \\
\hline FVC (\% pred.) & $92.9 \pm 9.7$ & $93.8 \pm 9.8$ & 0.556 \\
\hline $\mathrm{FEV}_{1}$ (\% pred.) & $84.5 \pm 8.2$ & $86.1 \pm 8.6$ & 0.225 \\
\hline $\mathrm{FEV}_{1} / \mathrm{FVC} \%$ & $73.1 \pm 4.7$ & $74.6 \pm 5.3$ & 0.057 \\
\hline $\mathrm{MEF}_{25}(\%$ pred. $)$ & $57.2 \pm 6.9$ & $60.5 \pm 7.1$ & 0.003 \\
\hline $\mathrm{MEF}_{50}^{25}$ (\% pred.) & $57.9 \pm 7.1$ & $61.6 \pm 7.3$ & 0.001 \\
\hline $\operatorname{MEF}_{75}$ (\% pred.) & $58.9 \pm 6.5$ & $62.1 \pm 7.1$ & 0.003 \\
\hline $\operatorname{MEF}_{25.75}$ (\% pred.) & $61.5 \pm 7.7$ & $63.7 \pm 8.1$ & 0.077 \\
\hline
\end{tabular}

Table 3 gives an overview of mean values of spirometric parameters in construction workers with exposure duration more than 20 years and those with $<20$ years.

Table 3: Mean values of spirometric parameters in construction workers according to the exposure duration

\begin{tabular}{|c|c|c|c|}
\hline $\begin{array}{l}\text { Spirometric } \\
\text { parameters }\end{array}$ & $\begin{array}{l}\text { Exposed }>20 \text { years } \\
(n=59)\end{array}$ & $\begin{array}{l}\text { Exposed } \leq 20 \text { years } \\
(\mathrm{n}=24)\end{array}$ & p-value * \\
\hline FVC (\% pred.) & $91.8 \pm 9.2$ & $93.5 \pm 9.4$ & 0.450 \\
\hline $\mathrm{FEV}_{1}(\%$ pred. $)$ & $85.1 \pm 8.7$ & $86.4 \pm 9.2$ & 0.545 \\
\hline $\mathrm{FEV}_{1} / \mathrm{FVC} \%$ & $71.7 \pm 5.6$ & $73.8 \pm 4.9$ & 0.112 \\
\hline $\mathrm{MEF}_{25}(\%$ pred. $)$ & $56.8 \pm 6.5$ & $58.1 \pm 6.8$ & 0.417 \\
\hline $\operatorname{MEF}_{50}$ (\% pred.) & $56.2 \pm 6.4$ & $59.3 \pm 6.3$ & 0.047 \\
\hline $\operatorname{MEF}_{75}$ (\% pred.) & $57.2 \pm 6.3$ & $60.7 \pm 6.8$ & 0.027 \\
\hline $\operatorname{MEF}_{25-75}$ (\% pred.) & $59.8 \pm 7.2$ & $61.1 \pm 7.4$ & 0.461 \\
\hline
\end{tabular}

The mean values of spirometric parameters are lower in construction workers exposed more than 20 years compared to those with exposure duration $<20$ years, being significant for $\mathrm{MEF}_{50}$ and $\mathrm{MEF}_{75}$.

A certain number of subjects from EG and CG were diagnosed with mild and moderate degree of restrictive, obstructive, and combined ventilatory impairment and obstructive ventilatory pattern in small airways (Table 4).

Table 4: Subjects from EG and CG with registered ventilatory impairment

\begin{tabular}{|c|c|c|c|c|}
\hline Type of ventilatory impairment & $E G(n=83)$ & CG $(n=80)$ & p-value * & OR $(95 \% \mathrm{Cl})$ \\
\hline $\begin{array}{l}\text { Any type of ventilatory } \\
\text { impairment }\end{array}$ & $30(37.5 \%)$ & $14(17.5 \%)$ & $p=0.007$ & $2.67(1.21-5.92)$ \\
\hline Restrictive ventilatory pattern & $2(2.4 \%)$ & $1(1.3 \%)$ & $p=0.581$ & $1.95(0.14-55.50)$ \\
\hline $\begin{array}{l}\text { Obstructive and combined } \\
\text { ventilatory pattern }\end{array}$ & $13(15.6 \%)$ & $5(6.3 \%)$ & $p=0.050$ & $2.79(0.86-9.50)$ \\
\hline $\begin{array}{l}\text { Obstructive ventilatory pattern } \\
\text { in small airways }\end{array}$ & $29(34.9 \%)$ & $14(17.5 \%)$ & $p=0.011$ & $2.53(1.15-5.63)$ \\
\hline
\end{tabular}


According to the results shown in Table 4, there is a significant difference in detected ventilatory impairment between exposed workers and controls for any type of ventilatory impairment, as well as obstructive and combined ventilatory pattern and obstructive ventilatory pattern in small airways.

There is a non-significantly higher frequency of restrictive ventilatory pattern in exposed workers, while restrictive ventilatory impairment is non-significantly associated with gender, age, place of residence (village/city), body mass index (BMI), and family history of asthma and allergic diseases.

Mild and moderate obstructive and combined ventilatory impairment are significantly more frequent among construction workers compared to controls. The risk for obstructive and combined ventilatory impairment is about 2.8 fold higher in subjects of EG, compared to those of $C G$ (odds ratio [OR] = 2.79 [0.86-9.50] Cl 95\%), while obstructive type of ventilatory impairment is nonsignificantly associated with age, place of residence (village/city), and BMI.

Obstructive ventilatory pattern in small airways is significantly more prevalent in construction workers, having about 2.5 fold higher risk (OR $=2.53$ [1.15-5.63] $\mathrm{Cl} 95 \%$ ), but is non-significantly associated with age, place of residence (village/city), and BMI.

Association between the type of ventilatory impairment among smokers in EG and CG and life-time smoking, number of cigarettes smoked daily, as well as the combined effect of daily smoking, life-time smoking, and number of cigarettes smoked daily is shown in Table 5.

Table 5: Association between the types of ventilatory impairment among smokers and life-time smoking, number of cigarettes smoked daily, as well as the combined effect of daily smoking, life-time smoking, and number of cigarettes smoked daily in subjects of EG and CG

\begin{tabular}{|c|c|c|}
\hline Variable & EG $(p)$ & CG (p) \\
\hline \multicolumn{3}{|l|}{ Restrictive ventilatory pattern } \\
\hline Life-time smoking (years) & $\mathrm{NS}^{*}$ & $\mathrm{NS}^{*}$ \\
\hline Cigarettes/day & $\mathrm{NS}^{\star}$ & $\mathrm{NS}^{*}$ \\
\hline Daily smoking/life-time smoking/cigarettes/day & $\mathrm{NS}^{* *}$ & $N S^{* *}$ \\
\hline \multicolumn{3}{|l|}{ Obstructive and combined ventilatory pattern } \\
\hline Life-time smoking (years) & $\begin{array}{l}p<0.05^{\star} \\
\text { Beta }=0.202\end{array}$ & $\mathrm{NS}^{*}$ \\
\hline Cigarettes/day & $\mathrm{NS}^{*}$ & $\mathrm{NS}^{*}$ \\
\hline Daily smoking/life-time smoking/cigarettes/day & $\mathrm{NS}^{* *}$ & $\mathrm{NS}^{* *}$ \\
\hline \multicolumn{3}{|l|}{ Obstructive ventilatory pattern in small airways } \\
\hline Life-time smoking (years) & $\begin{array}{l}p<0.05^{*} \\
\text { Beta }=0.214\end{array}$ & $N S^{*}$ \\
\hline Cigarettes/day & $\mathrm{NS}^{*}$ & $\mathrm{NS}^{*}$ \\
\hline Daily smoking/life-time smoking/cigarettes/day & $\begin{array}{l}p<0.05^{* *} \\
\text { Beta }=0.137\end{array}$ & $N S^{* *}$ \\
\hline
\end{tabular}

According to Table 5, obstructive ventilatory impairment is significantly associated only with life-time smoking in construction workers who smoke $(p<0.05)$, while association with cigarettes smoked daily is nonsignificant in both groups.

Combined effect of daily smoking, life-time smoking, and number of cigarettes smoked daily have a non-significant impact on the development of obstructive ventilatory impairment in both groups.
Obstructive ventilatory pattern in small airways is significantly associated with life-time smoking in construction workers who smoke $(p<0.05)$, whereas the combined effect of daily smoking, life-time smoking, and number of cigarettes smoked daily has a significant influence in their development.

The association of different types of ventilatory impairment with chronic nasal and respiratory symptoms in both groups is shown in Table 6 .

Table 6: Association of nasal and respiratory symptoms with the types of ventilatory impairment

\begin{tabular}{lll}
\hline Variable & $\mathrm{EG}\left(\mathrm{p}^{*}\right)$ & $\mathrm{CG}\left(\mathrm{p}^{*}\right)$ \\
\hline Restrictive ventilatory pattern & $\mathrm{NS}$ & \\
Nasal symptoms & $\mathrm{NS}$ & $\mathrm{NS}$ \\
Cough & $\mathrm{NS}$ & $\mathrm{NS}$ \\
Cough with phlegm & $\mathrm{p}<0.05$ & $\mathrm{p}<0.05$ \\
Dyspnea & $\mathrm{NS}$ & $\mathrm{NS}$ \\
Wheezing & $\mathrm{NS}$ & $\mathrm{NS}$ \\
Chest tightness & $\mathrm{NS}$ & $\mathrm{NS}$ \\
Obstructive and combined ventilatory pattern & $\mathrm{p}<0.05$ & $\mathrm{p}<0.05$ \\
Nasal symptoms & $\mathrm{p}<0,05$ & $\mathrm{NS}$ \\
Cough & $\mathrm{P}<0.01$ & $\mathrm{p}<0.05$ \\
Cough with phlegm & $\mathrm{p}<0.05$ & $\mathrm{p}<0.05$ \\
Dyspnea & $\mathrm{NS}$ & $\mathrm{NS}$ \\
Wheezing & $\mathrm{NS}$ & $\mathrm{NS}$ \\
Chest tightness & $\mathrm{p}<0.05$ & $\mathrm{NS}$ \\
Obstructive ventilatory pattern in small airways & $\mathrm{NS}$ \\
Nasal symptoms & $\mathrm{p}<0.05$ & $\mathrm{NS}$ \\
Cough & $\mathrm{p}<0.05$ & $\mathrm{NS}$ \\
Cough with phlegm & $\mathrm{NS}$ & $\mathrm{NS}$ \\
Dyspnea & $\mathrm{NS}$ & \\
Wheezing & & \\
Chest tightness & &
\end{tabular}

Restrictive ventilatory impairment is significantly associated with dyspnea $(p<0.05)$ in both EG, while obstructive ventilatory impairment is significantly associated with cough, dyspnea, and wheezing in both groups and with cough with phlegm in construction workers only. Obstructive ventilatory pattern in small airways is significantly associated with cough, cough with phlegm, and dyspnea among construction workers.

Association between obstructive ventilatory impairment and obstructive ventilatory pattern in small airways, exposure duration, and daily smoking among subjects in EG and CG is given in Table 7.

Table 7: Association between obstructive ventilatory impairment and obstructive ventilatory pattern in small airways, exposure duration, and daily smoking among subjects in EG and CG

\begin{tabular}{|c|c|c|c|c|}
\hline Variable & $E G(n=83)$ & $\mathrm{p}^{\star}$ & GG $(n=80)$ & $p^{\star \star}$ \\
\hline \multicolumn{5}{|l|}{ Obstructive and combined ventilatory pattern } \\
\hline $\begin{array}{l}\text { Exposure duration } \leq 20 \text { years with } \\
\text { obstructive ventilatory pattern }\end{array}$ & $2 / 24(8.3 \%)$ & NS & I & I \\
\hline $\begin{array}{l}\text { Exposure duration }>20 \text { years with } \\
\text { obstructive ventilatory pattern }\end{array}$ & $11 / 59(18.6 \%)$ & $p=0.328$ & I & \\
\hline $\begin{array}{l}\text { Daily smokers with obstructive } \\
\text { ventilatory pattern }\end{array}$ & $10 / 39(25.6 \%)$ & $p=0.044$ & $3 / 39(7.7 \%)$ & NS \\
\hline $\begin{array}{l}\text { Non-smokers with obstructive } \\
\text { ventilatory pattern }\end{array}$ & $4 / 44(9.1 \%)$ & & $2 / 41(4.9 \%)$ & 0.671 \\
\hline \multicolumn{5}{|l|}{ Obstructive ventilatory pattern in small airways } \\
\hline $\begin{array}{l}\text { Exposure duration } \leq 20 \text { years with } \\
\text { obstructive ventilatory pattern in small } \\
\text { airways }\end{array}$ & $4 / 24(16.7 \%)$ & $p=0.025$ & l & I \\
\hline $\begin{array}{l}\text { Exposure duration }>20 \text { years with } \\
\text { obstructive ventilatory pattern in small } \\
\text { airways }\end{array}$ & $25 / 59(42.4 \%)$ & & I & \\
\hline $\begin{array}{l}\text { Daily smokers with obstructive } \\
\text { ventilatory pattern in small airways }\end{array}$ & $18 / 39(46.1 \%)$ & $p=0.043$ & $9 / 39(23.1 \%)$ & NS \\
\hline $\begin{array}{l}\text { Non-smokers with obstructive } \\
\text { ventilatory pattern in small airways }\end{array}$ & $11 / 44(25 \%)$ & & $5 / 41(12.2 \%)$ & 0.200 \\
\hline
\end{tabular}


The risk for development of obstructive ventilatory impairment among construction workers is non-significantly higher in subjects exposed more than 20 years compared to those with shorter exposure $(\mathrm{OR}=0.40$ [0.06-2.16] $\mathrm{Cl} 95 \%)$ and is significantly higher in smokers compared to non-smokers (OR $=3.45$ [0.87-14.67] Cl 95\%). The risk for obstructive ventilatory impairment in controls is non-significantly higher among smokers $(\mathrm{OR}=1.63$ [0.20-14.92] Cl 95\%).

The risk for obstructive ventilatory pattern in small airways among exposed subjects is about 4 fold higher in those exposed more than 20 years $(\mathrm{OR}=3.68$ [1.01-14.59] $\mathrm{Cl} 95 \%$ ), and about 2.5 fold higher in smokers (OR $=2.57$ [0.92-7.25] Cl 95\%), whereas it is non-significantly higher in controls who smoke (OR = 2.16 [0.57-8.43] Cl 95\%).

The effects of exposure duration in construction sites, smoking, and age on lung functional parameters are shown in Table 8.

Table 8: Effect of exposure duration, smoking, and age on lung functional parameters

\begin{tabular}{|c|c|c|}
\hline Variables & Beta & $p$ \\
\hline \multicolumn{3}{|l|}{$\overline{F V C}$} \\
\hline Age & -0.158 & 0.476 \\
\hline Exposure duration & -0.093 & 0.653 \\
\hline Smoking (pack-years) & 0.174 & 0.264 \\
\hline \multicolumn{3}{|l|}{$\mathrm{FEV}_{1}$} \\
\hline Age & -0.238 & 0.149 \\
\hline Exposure duration & -0.197 & 0.439 \\
\hline Smoking (pack-years) & 0.298 & 0.426 \\
\hline \multicolumn{3}{|l|}{$\mathrm{FEV}_{1} / \mathrm{FVC} \%$} \\
\hline Age & -0.475 & $0.044^{*}$ \\
\hline Exposure duration & -0.482 & $0.042^{*}$ \\
\hline Smoking (pack-years) & 0.097 & 0.679 \\
\hline \multicolumn{3}{|l|}{$\mathrm{MEF}_{25-75}$} \\
\hline $\mathrm{Age}^{25-75}$ & -0.398 & 0.086 \\
\hline Exposure duration & -0.497 & $0.038^{*}$ \\
\hline Smoking (pack-years) & 0.465 & $0.045^{*}$ \\
\hline
\end{tabular}

Linear regression analysis showed that exposure duration, smoking, and age had an independent effect on $\mathrm{MEF}_{25-75}$ and $\mathrm{FEV}_{1} / \mathrm{FVC} \%$ and no effect on other functional parameters.

\section{Discussion}

Lung functional impairment and chronic respiratory disorders are still important clinical and public health issues for the construction sector globally. A significant risk for respiratory morbidity and mortality among construction workers was observed by numerous studies within the last decades, documenting the relationship between occupational exposure to respiratory hazards in construction and occurrence of chronic respiratory symptoms, which afterward results in the development of chronic lung diseases [23].

Many studies report that occupational exposure to mineral dusts and cement particles may cause respiratory impairment of different type and severity. In addition, there is evidence that occupational exposure to mineral dust may lead to respiratory impairment independent of any effect due to smoking and separate from other effects of exposure such as pneumoconiosis, asthma, and COPD [24].

In the present study, we compared the prevalence of respiratory functional impairments in the last 12 months through the spirometric measurements in construction workers exposed to different types of mineral dusts with those in unexposed controls and further examined its relation to exposure duration and smoking habit.

According to the literature, various types of exposure to irritating or toxic substances are often accompanied with development of chronic occupational respiratory diseases [18]. Their incidence and prevalence rates depend upon the chemical composition of dust, particle size, exposure duration, and individual susceptibility [25]. Work operations in construction such as drilling, blasting, and grinding generate a large amount of dust which becomes airborne and inhalation of these particles may induce accelerated lung function decline [26]. After inhalation of the airborne dusts, many scavenger cells like macrophages usually dissolve these particles by surrounding them, but nevertheless, if there is too much dust concentration, the macrophages are unable to completely clear the dust, so it starts to irritate the lungs setting up an inflammation process in the small airways and lung sacs. As the inflammation starts healing, it produces fibrosis [27], [28]. Construction workers are less exposed to dust compared to workers in cement factory, quarry workers, and tunnel workers. The present study was set and conducted to investigate the doseresponse of dust exposure duration in a construction site on the lung functional parameters. The results show an association between pulmonary function impairment and exposure duration. On the other hand, this type of study gives very little consideration to other confounding factors which affect the lung functional status, such as age and smoking habit. Therefore, the present study was designed to assess the effects of airborne dusts on lung function among construction workers, matched for age, height, and weight. The obtained results showed that construction workers exposed $<5$ years had not particular lung functional impairment compared to controls. In addition, workers exposed for 6-20 years showed some reductions in lung function, while those with exposure above 20 years had a significant reduction in pulmonary function. Our study results showed that mean values of spirometric parameters were lower in construction workers exposed more than 20 years compared to those with exposure duration $<20$ years, being significant for $\mathrm{MEF}_{50}$ and $\mathrm{MEF}_{75}$. It is consistent with the findings of many studies that low concentration of silica exposure takes usually more than 10 years to develop chronic silicosis, whereas increased exposure duration within the construction sites increases the lung damage causing both airway obstruction and 
interstitial involvement. Oliver et al. studied the lung function of workers in highway construction and found that FEV1 values in these workers are lower than predicted ones putting them at increased risk for asthma [29]. Krzyzanowski et al. conducted a survey among workers exposed to dust found in building material and in pottery industry and found an annual rate of FEV1 decline due to occupational exposure [30]. Bakke et al. have registered an annual decrease of 21 $\mathrm{ml}$ in FEV1 among low silica dust exposed non-smokers engaged in tunnel construction [10]. Ulvestad et al. conducted a study to explore the association between dust exposure and airway inflammation and found lower airway inflammation even though workers were exposed for only 1 year [27]. Our actual study showed a decreased FEV1 values which is in accordance with the observations made by previously mentioned authors. Green et al. showed the effect of long-term exposure to mineral dust in young Indian adults, observing that FVC was significantly lower in the exposed group compared to controls [31]. Analyzing the influence of exposure time to silica on pulmonary function in stone quarry workers, Bagatin et al. found that FVC, FEV1, and FEV1/FVC\% are reduced in exposed group, showing that at the beginning, only peripheral airways are involved, but if the duration of exposure is extended, large airways are also affected [32]. Chia et al. reported that small airway obstruction is seen in the absence of radiological evidence [33]. The relationship between dust exposure and ventilatory function among cement workers was investigated by Yang et al. and the results showed that cement dust may lead to a high prevalence of chronic respiratory diseases and reduction of ventilatory capacities. The results pointed out that the exposed workers had reduced FVC, FEV1, and MEF25-75\% values [34]. Al-Neaimi et al. observed that average values of FVC, FEV1, FEV1/FVC\%, and PEFR were significantly reduced among cement workers in rapidly developing countries [35]. Mathur et al. reported a PEFR decrease in silica exposed workers compared to healthy adults [36]. Purdue et al. showed that impaired lung function, being obstructive, or restrictive, is associated with dust exposure among construction workers [37]. The decline in FEV1 is a convenient standard in subjects with a history of COPD or exposure to environmental pollutants, whereas PEFR values provide an objective assessment of functional changes associated with environmental and occupational exposures, showing both acute and chronic disease processes in patients with severe COPD [38]. Our results suggest that dust in construction site affects lung function, leading to a decrease in the lung function parameters (FVC, FEV1, FEV1/FVC\%, and MEF25-75\%), confirming that these parameters are very sensitive in detecting changes in pulmonary function at an early stage.

Occupational exposure of construction workers to respirable dusts and crystalline silica dust was extensively studied by within the last two decades, especially among Canadian and American construction workers [39], [40]. Excessive exposure in our study might be due to a lack of engineering control measures and higher percentage of crystalline silica in cement and respirable dusts, compared with other countries. Due to the lack of reliable data about respiratory health among the construction workers in our country, in our study, we have examined the workers' lung function parameters. The mean values of spirometric parameters were lower in construction workers compared to controls, but statistical significance was registered for $\mathrm{MEF}_{25}$, $\mathrm{MEF}_{50}$, and $\mathrm{MEF}_{75}$. Having in mind the obtained results, a significant relationship was detected between exposure to dusts and reduction in lung functional parameters, which is in line with the reported results in similar studies conducted by Johncy et al., Al-Neaimi et al., Poornajaf et al., and Kakooei et al. [2], [34], [41]. Tjoe-Nij et al. found that obstructive ventilatory pattern is associated with exposure to crystalline silica in construction workers [42]. However, in the study of Tavakol et al., more than half of construction workers (51.8\%) were diagnosed with a moderate restrictive ventilatory pattern, and only $4.70 \%$ were classified as obstructive ventilatory pattern [12]. This observation may be due to the higher exposure of Iranian workers to crystalline silica with the restrictive ventilatory pattern [43]. Another cause for this may be the fact that examined construction workers were non-smokers, having in mind that smoking is one of the main risk factors for COPD development, resulting in obstructive ventilatory impairment [44]. Our study revealed the fact that there was a significant difference in detected ventilatory impairment between exposed workers and controls for any type of ventilatory impairment, as well as obstructive and combined ventilatory pattern and obstructive ventilatory pattern in small airways. Obstructive ventilatory impairment was significantly associated with life-time smoking in construction workers, obstructive ventilatory pattern in small airways was significantly associated with life-time smoking, whereas the combined effect of daily smoking, life-time smoking, and number of cigarettes smoked daily had a significant influence in their development.

The results of our present study confirmed the lung function decline in construction workers incomparison with controls working in cleaner environments. Several studies have shown the association between inhalation of cement dust and impairment of lung functional tests [45], [46]. FVC and FEV1 decline as age increases, as a part of the normal aging process, but an enhanced or accelerated decline occurs in lung disorders, of which occupational exposure to dust particles is one of the reasons. The findings in our study correlate with another previous study which observes a FEV1 decline due to exposure to dust and cement particulate matter, further leading to altered airway patency [47]. Inhaled cement and dust particles at construction sites, gain entry into lungs, get lodged, and cause lung irritation, mucus hypersecretion, inflammation of lung parenchyma which lead to decreased lung function predisposing to chronic 
obstructive and restrictive lung diseases as well as pneumoconiosis [36], [38].

Our actual study has some limitations. A relatively small number of examined participants in the study groups may be a limiting factor and probably has certain implications on the obtained results. Furthermore, the absence of ambient monitoring and measurement of dust concentration could aggravate a clear relationship between the severity of occupational exposure and lung function impairment.

\section{Conclusion}

The actual study found that mean values of spirometric parameters were lower in construction workers compared to controls with statistical significance registered for $\mathrm{MEF}_{25}, \mathrm{MEF}_{50}$, and $\mathrm{MEF}_{75}$. Lung functions of construction workers have been found to decrease in relation to exposure duration but reached significance only for small airways changes. There was a significant difference in detected ventilatory impairment between exposed workers and controls for any type of ventilatory impairment, as well as obstructive and combined ventilatory pattern and obstructive ventilatory pattern in small airways. Obstructive ventilatory impairment was significantly associated with life-time smoking in construction workers, while obstructive ventilatory pattern in small airways was significantly associated with life-time smoking. The combined effect of daily smoking, life-time smoking, and number of cigarettes smoked daily was shown to have a significant influence in their development. The risk for obstructive ventilatory pattern in small airways among exposed subjects was about 4 fold higher in those exposed more than 20 years and about 2.5 fold higher in smokers. Exposure duration, smoking, and age had independent effect only on small airways changes and $\mathrm{FEV}_{1} / \mathrm{FVC} \%$. The obtained results recognized the role and importance of occupational exposure among construction workers in the development of respiratory impairment but also confirmed the interaction with daily smoking on airflow limitation with predominantly smaller airways affecting. Thus, it is necessary to implement adequate preventive measures focused on smoking cessation and tobacco control activities to avoid the interaction of smoking and job exposure to respiratory hazards.

\section{References}

1. Healy CB, Coggins MA, van Tongeren M, MacCalman L, McGowan P. Determinants of respirable crystalline silica exposure among stoneworkers involved in stone restoration work. Ann Occup Hyg. 2014;58(1):6-18. https://doi.org/10.1520/ stp156520120219

PMid:23997236

2. Johncy SS, Ajay KT, Dhanyakumar G, Raj NP, Samuel TV. Dust exposure and lung function impairment in construction workers. J Physiol Biomed Sci. 2011;24:9-13.

3. Yassin A, Yebesi F, Tingle R. Occupational exposure to crystalline silica dust in the United States, 1988-2003. Environ Health Perspect. 2005;113(3):255-60. https://doi.org/10.1289/ ehp.7384

PMid:15743711

4. Bujak-Pietrek S, Szadkowska-Stańczyk I. Dust exposure assessment among construction workers in Poland, 2001-2005. Med Pr. 2009;60(4):247-57.

PMid:19928425

5. McLean D, Glass B, 't Mannetje A, Douwes J. Exposure to respirable crystalline silica in the construction industry-do we have a problem? N Z Med J 2017;130(1466):78-82.

PMid:29197904

6. Meo SA, Al-Drees AM, Al Masri AA, Al Rouq F, Azeem MA Effect of duration of exposure to cement dust on respiratory function of non-smoking cement mill workers. Int $\mathrm{J}$ Environ Res Public Health. 2013;10(1):390-8. https://doi.org/10.3390/ ijerph10010390

PMid:23325026

7. Yeheyis M, Aguilar G, Hewage K, Sadiq R. Exposure to crystalline silica inhalation among construction workers: A probabilistic risk analysis. Hum Ecol Risk Assess. 2012;18(5):1036-50. https:// doi.org/10.1080/10807039.2012.707931.

8. Mariammal T, Amutha AJ, Sornaraj R. Work related respiratory symptoms and pulmonary function tests observed among construction and sanitary workers of Thoothukudi. Int J PharmTech Res. 2012;4:1266-73.

9. Flanagan M.E, Seixas N, Majar M, Camp J, Morgan M. Silica dust exposures during selected construction activities. AlHA J. 2003;64(3):319-28. https://doi. org/10.1080/15428110308984823 PMid:12809537

10. Bakke B, Ulvestad B, Stewart P, Eduard W. Cumulative exposure to dust and gases as determinants of lung function decline in tunnel construction workers. Occup Environ Med. 2004;61(3):262-9. https://doi.org/10.1136/oem.2003.008409 PMid:14985522

11. Sivaharini S, Preetha S, Priya J. Evaluation of pulmonary function test in construction workers. Drug Invent Today. 2018; 10:2148-51.

12. Tavakol E, Azari M, Zendehdel R, Salehpour S, Khodakrim S, Nikoo S, et al. Risk evaluation of construction workers' exposure to silica dust and the possible lung function impairments. Tanaffos. 2017;16(4):295-303

PMid:29849687

13. Park K. Occupational health. In: Park's Textbook of Preventive and Social Medicine. $18^{\text {th }}$ ed. Jabalpur: M/s Banarsidas Bhanot; 2007. p. 608-10.

14. Nij ET, Hilhorst S, Spee T, Spierings J, Steffens F, Lumens M, et al. Dust control measures in the construction industry. Ann Occup Hyg. 2003;47(3):211-8. PMid:12639834

15. Mengesha YA, Bekele A. Effects of acute exposure to different occupational dusts on pulmonary function indices of factory workers in Ethiopia. Afr Newslett Occup Health Safety. 1997;7:8-9.

16. Mwaiselage J, Moen B, Bråtveit M. Acute respiratory health effects among cement factory workers in Tanzania: An evaluation of a simple health surveillance tools. Int Arch Occup Environ Health. 2005;79(1):49-56. https://doi.org/10.1007/ 
s00420-005-0019-x

PMid: 16049720

17. Minette A. Questionnaire of the European community for coa and steel (ECSC) on respiratory symptoms. 1987 updating of the 1962 and 1967 questionnaires for studying chronic bronchitis and emphysema. Eur Respir J. 1989;2(2):165-77.

PMid:2703044

18. European Community Respiratory Health Survey. Variations in the prevalence of respiratory symptoms, self-reported asthma attacks, and use of asthma medication in the European Respiratory Health Survey (ECRHS). Eur Respir J. 1996;9(4):687-95. https://doi.org/10.1183/09031936.96.0904 0687

PMid:8726932

19. World Health Organization. Guidelines for Controlling and Monitoring the Tobacco Epidemic. Geneva: World Health Organization; 1998.

20. Smoking Pack-Years; 2013. Available from: http://www. smokingpackyears.com/calculate. [Last accessed on 2019 Apr 15].

21. US Department of Health and Human Services. The Health Consequences of Smoking: Chronic Obstructive Pulmonary Disease. A Report of the Surgeon General; 1984. Available from: http://www.profiles.nlm.nih.gov/ps/access/NNBCCS.pdf. [Last accessed on 2019 Mar 16].

22. Quajner PH, Tammeling GJ, Cotes JE, Pedersen OF, Peslin R, YernaultJC. Lung volumes and forced ventilatory flows. Eur Respir J. 1993;16(1):5-40. https://doi.org/10.1183/09041950.005s1693 PMid:24576915

23. Sulaiman NN, Awang $N$, Kamaludin NF, Riduan AN, Abdul Rahman SA. Evaluation of pulmonary function status of the construction site's workers. Asian J Sci Res. 2020;13:175-80.

24. Danilova M, Stoleski S, Mijakoski D. Respiratory symptoms and ventilatory function in never-smoking males working in dusty occupations. OA Maced J Med Sci. 2014;2(4):645-9. https://doi. org/10.3889/oamjms.2014.116

25. Kasper DL, Braunwald E, Fauci AS, Hauser SL, Longo DL, Jameson JL. Environmental lung diseases. In: Harrison's Principles of Internal Medicine. Vol. 2. $16^{\text {th }}$ ed. New York: McGraw-Hill; 2008. p. 1521-7. https://doi. org/10.1111/j.1445-5994.2008.01837.x

26. Ulvestad B, Lund MB, Bakke B, Djupesland PG, Kongerud J, Boe J. Gas and dust exposure in underground construction is associated with signs of airway inflammation. Eur Respir J. 2001;17(3):416-21. https://doi.org/10.1183/09031936.01.1730 4160

\section{PMid: 11405519}

27. Tjoe Nij E, Hilhorst S, Spee T, Spierings J, Steffens F, Lumens M, et al. Dust control measures in the construction industry. Ann Occup Hyg. 2003;47(3):211-8. PMid:12639834

28. Seaton A. Silicosis. In: Morgan WK, Seaton A, editors Occupational Lung Diseases. $3^{\text {rd }}$ ed. Philadelphia, PA: WB Saunders; 1995. p. 222-37.

29. Oliver LC, Miracle-McMahill H, Littman AB, Oakes JM Gaita RR Jr. Respiratory symptoms and lung function in workers in heavy and highway construction: A cross-sectional study. Am J Ind Med. 2001;40(1):73-86. https://doi.org/10.1002/ajim.1073 PMid:11439399

30. Krzyzanowski M, Jedrychowski W, Wysocki M. Occupational exposures and changes in pulmonary function over 13 years among residents of Cracow. Br J Ind Med. 1998;45(11):747-54. https://doi.org/10.1136/oem.45.11.747 PMid:3203079

31. Green DA, McAlphine G, Semple S, Cowie H, Seaton A. Mineral dust exposure in young Indian adults: An effect on lung growth. Occup Environ Med. 2008;65(5):306-10. https://doi.org/10.1136/ oem.2007.032797

PMid:17522138

32. Bagatin E, Juliano Y, Novo NF, Jardim JR. Influence of exposure time to silica and smoking on pulmonary function of workers in the ceramic and stone quarry workers. Amb Rev Assoc Med Bras. 1991;37(2):85-90.

PMid: 1658877

33. Chia KS, Ng TP, Jeyaratnam J. Small airway function of silica exposed workers. Am J Ind Med. 1992;22(2):155-62. https://doi. org/10.1002/ajim.4700220203

PMid:1329507

34. Yang CY, Huang CC, Chiu HF, Chiu JF, Lan SJ, Ko YC. Effect of occupational dust exposure on the respiratory health of Portland cement workers. J Toxicol Environ Health. 1996;49(6):581-8. PMid:8977625

35. Al-Neaimi YI, Gomes J, Lloyd OL. Respiratory illnesses and ventilatory function among workers at a cement factory in a rapidly developing country. Occup Med (Lond). 2001;51(6):36773. https://doi.org/10.1093/occmed/51.6.367 PMid:11584114

36. Mathur ML, Dixit AK, Lakshminarayana J. Correlates of peak expiratory flow rate. A study of sand stone quarry workers in desert. Indian J Physiol Pharmacol. 1996;40(4):340-4.

PMid:9055104

37. Purdue MD, God L, Jarvholm B, Alavanja MC, Ward MH, Vermeulen R. Impaired lung function and lung cancer incidence in a cohort of Swedish construction workers. Thorax. 2007;62(1):51-6. https://doi.org/10.1136/thx.2006.064196 PMid: 16928722

38. Garshick E, Schenker MB, Dosman JA. Occupationally induced airway obstruction. Med Clin North Am. 1996;80(4):851-78. https://doi.org/10.1016/s0025-7125(05)70470-3

PMid:8676617

39. Flanagan ME, Seixas N, Becker P, Takacs B, Camp J. Silica exposure on construction sites: Results of an exposure monitoring data compilation project. J Occup Environ Hyg. 2006;3(3):144-52. https://doi.org/10.1080/15459620500526552 PMid: 16464818

40. Radnoff $D$, Todor MS, Beach J. Occupational exposure to crystalline silica atAlberta work sites. J Occup Environ Hyg. 2014;11(9):557-70. https://doi.org/10.1080/15459624.2014.887205 PMid:24479465

41. van Deurssen E, Pronk A, Spaan S, Goede H, Tielemans E, Heederik $D$, et al. Quartz and respirable dust in the Dutch construction industry: A baseline exposure assessment as part of a multidimensional intervention approach. Ann Occup Hyg. 2014;58(6):724-38. https://doi.org/10.1136/ oemed-2014-102362.359

PMid:24723463

42. Tjoe-Nij E, de Meer G, Smit J, Heederik D. Lung function decrease in relation to pneumoconiosis and exposure to quartz-containing dust in construction workers. Am J Ind Med. 2003;43(6):574-83. https://doi.org/10.1002/ajim.10229 PMid: 12768607

43. Imani $\mathrm{M}$, Heidari $\mathrm{H}$, Rahimifard $\mathrm{H}$, Mahdinia M, Haseli F, Azizi $\mathrm{F}$, et al. Assessment of occupational exposure to silica dust and respiratory effects in exposed workers in one of the ceramic products industry. Cumhuriyet Sci J. 2015;36(4):1893-8.

44. Celli BR, Decramer M, Wedzicha JA, Wilson KC, Agustí A, Criner GJ, et al. An official American thoracic society/European respiratory society statement: Research questions in chronic obstructive pulmonary disease. Am J Respir Crit Care Med. 
2015;191(7):e4-27. https://doi.org/10.1164/rccm.v202erratum5 PMid:25830527

45. Neghab M, Choobineh A. Work related respiratory symptoms and ventilatory disorders among employees of a cement industry in Shiraz, Iran. J Occup Health. 2007;49:273-8. https:// doi.org/10.1539/joh.49.273

46. Mwaiselage J, Bråtveit M, Moen B, Mashalla Y. Cement dust exposure and ventilatory function impairment: an exposureresponse study. J Occup Environ Med. 2004;46(7):658-67. https://doi.org/10.1097/01.jom.0000131787.02250.79

PMid:15247805

47. Mohamed E, A.Dalia. Occupational exposures as a cause of chronic obstructive pulmonary disease. Egyptian Journal of Bronchology, 2009;3(1):11-23. 